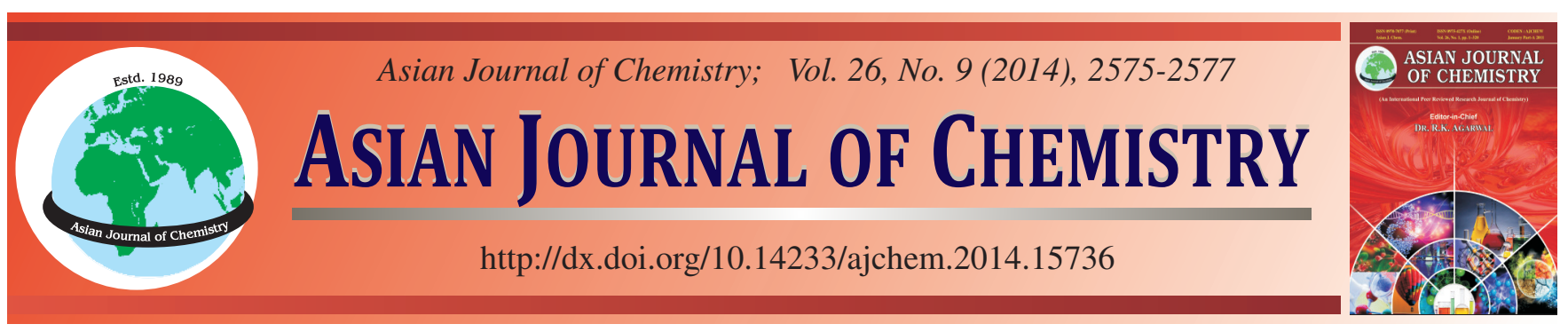

\title{
A New Phenylpropanoid from the Leaves of Flue-Cured Tobacco and Its Anti-Tobacco Mosaic Virus Activity
}

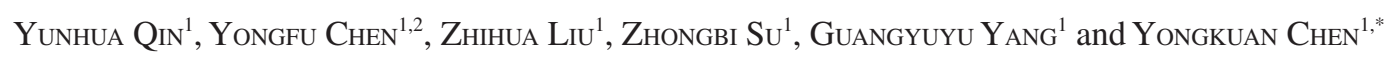

${ }^{1}$ Key Laboratory of Tobacco Chemistry of Yunnan Province, Yunnan Academy of Tobacco Science, Kunming 650106, P.R. China

${ }^{2}$ Technology Center of Hongta Group, Yuxi 653100, P.R. China

*Corresponding author: E-mail: cyk1966@163.com

Received: 7 May 2013;

Accepted: 17 August 2013;

Published online: 28 April 2014;

AJC-15072

\begin{abstract}
A new phenylpropanoid, nicotpanoid C (1), was isolated from the leaves of flue-cured tobacco (a variety of Nicotiana tabacum L). Its structure was elucidated by spectroscopic methods, including extensive 1D and 2D NMR techniques. Compound 1 was tested for its antitobacco mosaic virus (anti-TMV) activity and it shows modest anti-tobacco mosaic virus activity with inhibition rates of $22.4 \%$.
\end{abstract}

Keywords: Phenylpropanoid, Flue-cured tobacco, Anti-tobacco mosaic virus activity.

\section{INTRODUCTION}

Nicotiana tabacum L. is one of the most commercially valued agricultural crops in the world ${ }^{1,2}$. In addition to being used in cigarette industry, N. tabacum is also used as insecticide, anesthetic, diaphoretic, sedative and emetic agents in Chinese folklore medicine because of it containing many useful chemical compounds ${ }^{1,3-5}$.

In previous work, a number of bioactive compounds, such as terpenoids ${ }^{6-8}$, alkaloids ${ }^{9,10}$, lignans ${ }^{11,12}$, flavonoid ${ }^{13}$, phenylpropanoids $^{14-16}$, and the homologous, were isolated from this plant. Motivated by search for bioactive metabolites from this plant, the investigation on the chemical constituents of the leaves of flue-cured tobacco (a variety of Nicotiana tabacum L) was carried out. As a result, a new phenylpropanoid, nicotpanoid C (1), was isolated from this plant. In addition, the anti-tobacco mosaic virus (anti-TMV) activity of 1 was evaluated. This article deals with the isolation, structural elucidation and biological activities of this new compound.<smiles>COc1cc(/C=C/C(=O)O[C@@H]2C[C@](O)(C(=O)O)C[C@@H](O)[C@H]2O)cc(O)c1OC</smiles>

Structures of compound $\mathbf{1}$

\section{EXPERIMENTAL}

Optical rotation was measured in Horiba SEPA-300 high sensitive polarimeter. IR spectra were obtained in $\mathrm{KBr}$ disc on a Bio-Rad Wininfmred spectrophotometer. ESI-MS were measured on a VG Auto Spec-3000 MS spectrometer. ${ }^{1} \mathrm{H},{ }^{13} \mathrm{C}$ and 2D NMR spectra were recorded on Bruker DRX-500 instrument with TMS as internal standard. Column chromatography was performed on silica gel (200-300 mesh), or on silica gel H (10-40 $\mu \mathrm{m})$, Qingdao Marine Chemical Inc., China). Preparative HPLC was used an agilent 1100 HPLC equipped with ZORBAX-C $\mathrm{C}_{18}(21.2 \times 250 \mathrm{~mm}, 7.0 \mu \mathrm{m})$ column and DAD detector.

The leaves of flue-cured tobacco were collected in Yuxi Prefecture, Yunnan Province, People's Republic of China, in September 2011. The identification of the plant material was verified by Prof. Chen Y. J (Yunnan University of Nationalities).

Extraction and isolation: The air-dried and powdered leaves of oriental tobacco $(2.8 \mathrm{~kg})$ were extracted four times with $90 \%$ methanol $(4 \times 2.5 \mathrm{~L})$ at room temperature and filtered to yield a filtrate. The crude extract $(151 \mathrm{~g})$ was applied to silica gel (200-300 mesh) column chromatography, eluting with a $\mathrm{CHCl}_{3}-\left(\mathrm{CH}_{3}\right)_{2} \mathrm{CO}$ system $(20: 1,9: 1,8: 2,7: 3,6: 4,5: 5)$, to give six fractions A - F. The further purification of fraction D $(7: 3,18.3 \mathrm{~g})$ by silica gel column chromatography, eluted with $\mathrm{CHCl}_{3}-\mathrm{MeOH}(9: 1,8: 2,7: 3,6: 4,5: 5)$, yielded mixtures D1 - D5. Fraction D2 $(8: 2,1.82 \mathrm{~g})$ was subjected to preparative HPLC (28\% MeOH- $\mathrm{H}_{2} \mathrm{O}$, flow rate $\left.12 \mathrm{~mL} / \mathrm{min}\right)$ to yield compound 1 (12.6 mg). 
TABLE-1

${ }^{1} \mathrm{H}$ NMR AND ${ }^{13} \mathrm{C}$ NMR DATA OF COMPOUND $1\left(\mathrm{C}_{5} \mathrm{D}_{5} \mathrm{~N}, \delta, \mathrm{ppm}, / \mathrm{Hz}\right)$

\begin{tabular}{|c|c|c|c|c|c|}
\hline No. & $\delta_{\mathrm{C}}$ (mult.) & $\delta_{\mathrm{H}}(\mathrm{mult}, J, \mathrm{~Hz})$ & No. & $\delta_{\mathrm{C}}$ (mult.) & $\delta_{\mathrm{H}}($ mult $, J, \mathrm{~Hz})$ \\
\hline 1 & $132.4 \mathrm{~s}$ & & $2^{\prime}$ & $38.3 \mathrm{t}$ & 2.75-2.84, overlap \\
\hline 2 & $106.8 \mathrm{~d}$ & $6.52, \mathrm{~d}, J=1.8$ & & & 2.94-2.98, overlap \\
\hline 3 & $148.6 \mathrm{~s}$ & & 3' & $71.6 \mathrm{~d}$ & $6.20 \mathrm{~m}$ \\
\hline 4 & $139.5 \mathrm{~s}$ & & $4^{\prime}$ & $73.5 \mathrm{~d}$ & $4.38 \mathrm{~m}$ \\
\hline 5 & $152.2 \mathrm{~s}$ & & $5^{\prime}$ & $70.8 \mathrm{~d}$ & $4.82 \mathrm{~m}$ \\
\hline 6 & $104.9 \mathrm{~d}$ & $6.65, \mathrm{~d}, J=1.8$ & $6^{\prime}$ & $39.0 \mathrm{t}$ & 2.75-2.84, overlap \\
\hline 7 & $145.2 \mathrm{~d}$ & $7.76, \mathrm{~d}, J=15.5$ & $7^{\prime}$ & $176.8 \mathrm{~s}$ & 10.8 brs \\
\hline 8 & $116.8 \mathrm{~d}$ & $6.82, \mathrm{~d}, J=15.5$ & 4-OMe & $55.8 \mathrm{q}$ & $3.79 \mathrm{~s}$ \\
\hline 9 & $167.8 \mathrm{~s}$ & & $5-\mathrm{OMe}$ & $61.2 \mathrm{q}$ & $3.81, \mathrm{~s}$ \\
\hline $1^{\prime}$ & $76.6 \mathrm{~s}$ & & $\mathrm{Ar}-\mathrm{OH}$ & & $11.85 \mathrm{brs}$ \\
\hline
\end{tabular}

Nicotpanoid C (1): Obtained as a pale yellow gum; $[\alpha]_{\mathrm{D}}^{25}-46.8$ (c 0.20, MeOH); UV (MeOH), $\lambda_{\max }(\log \varepsilon) 326$ (3.92), 300 (3.68), 242 (4.08), 210 (4.36) nm; IR (KBr, $v_{\max }$, $\left.\mathrm{cm}^{-1}\right) 3382,2955,2873,1718,1705,1618,1536,1469,1421$, $1375,1250,1185,1055,958,864 ;{ }^{1} \mathrm{H}$ NMR and ${ }^{13} \mathrm{C}$ NMR data $\left(\mathrm{C}_{5} \mathrm{D}_{5} \mathrm{~N}, 500 \mathrm{MHz}\right.$ and $125 \mathrm{MHz}$, respectively), see Table1; ESIMS (positive ion mode), $m / z 421[\mathrm{M}+\mathrm{Na}]^{+}$; HRESIMS (positive ion mode), $\mathrm{m} / \mathrm{z} 421.1118[\mathrm{M}+\mathrm{Na}]^{+}$(calcd. 421.1111 for $\mathrm{C}_{18} \mathrm{H}_{22} \mathrm{NaO}_{10}$ ).

\section{RESULTS AND DISCUSSION}

Compound 1 was obtained as pale yellow gum. Its molecular formula was determined as $\mathrm{C}_{18} \mathrm{H}_{22} \mathrm{O}_{10}$ by HRESIMS, $\mathrm{m} / \mathrm{z} 421.1118[\mathrm{M}+\mathrm{Na}]^{+}$(calcd. 421.1111), corresponding to eight degrees of unsaturation. Its ${ }^{1} \mathrm{H}$ and ${ }^{13} \mathrm{C}$ NMR spectral data (Table-1) showed signals to 22 hydrogens and 18 carbons, respectively, corresponding to one aromatic ring $\left(\delta_{\mathrm{C}} 132.4 \mathrm{~s}\right.$, $106.8 \mathrm{~d}, 148.6 \mathrm{~s}, 139.5 \mathrm{~s}, 152.2 \mathrm{~s}, 104.9 \mathrm{~d})$ with two aromatic protons $\left(\delta_{\mathrm{H}} 6.52\right.$ (d) $J=1.8$ and 6.65 (d) $J=1.8$ ), one acryl group $\left(\delta_{\mathrm{C}} 145.2,116.8,167.8 ; \delta_{\mathrm{H}} 7.76\right.$ (d) $J=15.5,6.82$ (d) $J=15.5)$, one $3-O$-quinic acid group $\left(\delta_{\mathrm{C}} 76.6 \mathrm{~s}, 38.3 \mathrm{t}, 71.6 \mathrm{~d}\right.$, $73.5 \mathrm{~d}, 70.8 \mathrm{~d}, 39.0 \mathrm{t}, 176.8 \mathrm{~s} ; \delta_{\mathrm{H}} 2.75-2.84$ overlap, 2.94-2.98 overlap, $6.20 \mathrm{~m}, 4.38 \mathrm{~m}, 4.82 \mathrm{~m}, 2.75-2.84$ overlap, $10.8 \mathrm{brs})$, two methoxy groups $\left(\delta_{\mathrm{C}} 55.8 \mathrm{q}, 61.2 \mathrm{q} ; \delta_{\mathrm{H}} 3.79 \mathrm{~s}, 3.81 \mathrm{~s}\right)$ and one phenolic hydroxy group $\left(\delta_{\mathrm{H}} 11.85\right)$. Strong absorption bands accounting for hydroxy $\left(3382 \mathrm{~cm}^{-1}\right)$, carbonyl (1718, $\left.1705 \mathrm{~cm}^{-1}\right)$ and aromatic group $\left(1618,1536,1469,1421 \mathrm{~cm}^{-1}\right)$ could be observed in its IR spectrum. The UV spectrum of $\mathbf{1}$ showed absorption maxima at 326, 300, 242 and $210 \mathrm{~nm}$ also confirmed the existence of the aromatic function. The HMBC correlations (Fig. 1) of H-8 $\left(\delta_{\mathrm{H}} 6.82\right)$ with $\mathrm{C}-1\left(\delta_{\mathrm{C}} 132.4\right)$, of $\mathrm{H}-7\left(\delta_{\mathrm{H}} 7.76\right)$ with $\mathrm{C}-1\left(\delta_{\mathrm{C}} 132.4\right), \mathrm{C}-2\left(\delta_{\mathrm{C}} 106.8\right)$ and C-6 $\left(\delta_{\mathrm{C}}\right.$ 104.9), of H-2 $\left(\delta_{\mathrm{H}} 6.52\right)$ with $\mathrm{C}-7\left(\delta_{\mathrm{C}} 145.2\right)$ and of H-6 $\left(\delta_{\mathrm{H}}\right.$ $6.65)$ with $\mathrm{C}-7\left(\delta_{\mathrm{C}} 145.2\right)$ suggested the acryl (-CH=CH-COO) unit was attached to $\mathrm{C}-1$. The long-range correlations of two methoxy proton signals $\left(\delta_{\mathrm{H}} 3.79\right.$ and 3.81$)$ with $\mathrm{C}-4\left(\delta_{\mathrm{C}} 139.5\right)$ and $\mathrm{C}-5\left(\delta_{\mathrm{C}} 152.2\right)$ clearly indicated that two methoxy groups located at $\mathrm{C}-4$ and $\mathrm{C}-5$. The HMBC correlations of phenolic hydroxy proton signal $\left(\delta_{\mathrm{H}} 11.85\right)$ with $\mathrm{C}-2\left(\delta_{\mathrm{C}} 106.8\right), \mathrm{C}-3\left(\delta_{\mathrm{C}}\right.$ $148.6)$ and $\mathrm{C}-4\left(\delta_{\mathrm{C}} 139.5\right)$ indicated that the hydroxy group should be located at C-2. The HMBC correlation of H-3' $\left(\delta_{\mathrm{H}}\right.$ 6.20) with $\mathrm{C}-9\left(\delta_{\mathrm{C}} 167.8\right)$ indicated that the 3-O-quinic acid group should be located at C-9. Thus, the structure of $\mathbf{1}$ was established and it was named as nicotpanoid $\mathrm{C}$.

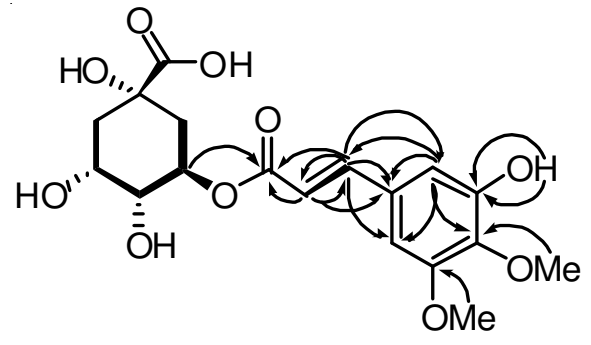

$\operatorname{HMBC}(\frown){ }^{1} \mathrm{H}^{-1} \mathrm{H} \operatorname{COSY}(-)$

Fig. 1. The key HMBC and ${ }^{1} \mathrm{H}-{ }^{1} \mathrm{H}$ COSY correlations of $\mathbf{1}$

Since certain of the phenylpropanoids exhibit potential Anti-TMV activity, compounds $\mathbf{1}$ was tested for it anti-tobacco mosaic virus activity. The anti-TMV activities were tested using the half-leaf method ${ }^{17}$. Ningnanmycin ( $2 \%$ water solution), a commercial product for plant disease in China, was used as a positive control. The results showed that compound 1 exhibited inhibition rates of $22.4 \%$.

\section{ACKNOWLEDGEMENTS}

This project was supported financially by the Basic Research Foundation of Yunnan Tobacco Industry Co. Ltd (2012JC01), the National Natural Science Foundation of China (No. 31360081), the Excellent Scientific and Technological Team of Yunnan High School (2010CI08).

\section{REFERENCES}

1. The Editorial Committee of the Administration Bureau of Flora of China, Flora of China, Vol. 67, Beijing Science and Technology Press, Beijing (2005).

2. T.W. Hu and Z. Mao, Tob. Control, 15, i37 (2006).

3. A. Rodgman and T.A. Perfetti, The Chemical Components of Tobacco and Tobacco Smoke, CRC Press, Taylor and Francis Group, Boca Raton, Florida (2008).

4. A.P. Cavender and M. Alban, J. Ethnobiol. Ethnomed., 5, 3 (2009).

5. I. Angkhana, S.J. Pei, B. Henrik and T. Chusie, J. Ethnopharm., 116, 134(2008).

6. X. Feng, J.S. Wang, J. Luo and L.Y. Kong, J. Asian Nat. Prod. Res., 12, 252 (2010).

7. Y. Shinozaki, T. Tobita, M. Mizutani and T. Matsuzaki, Biosci. Biotechnol. Biochem., 60, 903 (1996).

8. T. Petterson, A.M. Eklund and I. Wahlberg, J. Agric. Food. Chem., 41, 2097(1993).

9. X.C. Wei, S.C. Sumithran, A.G. Deaciuc, H.R. Burton, L.P. Bush, L.P. Dwoskin and P.A. Crooks, Life Sci., 78, 495 (2005).

10. T. Braumann, G. Nicolaus, W. Hahn and H. Elmenhorst, Phytochemistry, 29, 3693(1990). 
11. Y.K. Chen, X.S. Li, G.Y. Yang, Z.Y. Chen, Q.F. Hu and M.M. Miao, J. Asian. Nat. Prod. Res., 14, 450 (2012).

12. X.M. Gao, X.S. Li, X.Z. Yang, H.X. Mu, Y.K. Chen, G.Y. Yang and Q.F. Hu, Heterocycles. 85, 147 (2012).

13. Z.Y. Chen, J.L. Tan, G.Y. Yang, M.M. Miao, Z.Y. Chen and T.F. Li, Phytochem. Lett., 5, 233 (2012).

14. J.L. Tan, Z.Y. Chen, G.Y. Yang, M.M. Miao, Y.K. Chen and T.F. Li. Heterocycles. 83, 2381 (2011).
15. X.M. Gao, L.Y. Yang, Y.Q. Shen, L.D. Shu, X.M. Li and Q.F. Hu, Bull. Korean Chem. Soc., 33, 2447 (2012).

16. Z.L. Geng, S.H. Shang, X.J. Chen, and Y. Cao, Chin. Tob. Sci., 32, 84 (2011).

17. Q.F. Hu, B. Zhou, X.M. Gao, L.Y. Yang, L.D. Shu, Y.Q. Shen, G.P. Li, C.T. Che and G.Y. Yang, J. Nat. Prod., 75, 1909 (2012). 